To Maega $\mid$ Jurnal Pengabdian Masyarakat

Oktober 2021, Vol.4, No.3, hal, 341-350

$\operatorname{ISSN}(P): 2622-6332 ; \operatorname{ISSN}(E): 2622-6340$

http://www.ojs.unanda.ac.id/index.php/tomaega

\title{
Penerapan Interaksi Sosial Antar Masyarakat Melalui Moderasi Beragama Dan Sikap Toleransi di Desa Gentasari Kecamatan Kroya Kabupaten Cilacap
}

\author{
Linda Aulia Rahmah ${ }^{1}$, Asep Amaludin ${ }^{2}$ \\ ${ }^{1}$ Studi Agama-Agama, Ushulludin Adab dan Humaniora, Institut Agama Islam Negeri \\ Purwokerto \\ ${ }^{2}$ Dosen, Fakultas Dakwah, Institut Agama Islam Negeri Purwokerto \\ Email: Linda.aulia1612@gmail.com ${ }^{1}$, Asep@iainpurwokerto.ac.id $^{2}$
}

Article History:

Received: 08-09-2021; Received in Revised: 30-09-2021; Accepted: 12-10-2021

DOI: http://dx.doi.org/10.35914/tomaega.v4i3.860

\begin{abstract}
Abstrak
Moderasi Agama di Indonesia menjadi salah satu indikator yang penting dan dijadikan sebagai cara pandang (perspektif) dalam seluruh praktik kehidupan beragama sebab Indonesia memiliki berbagai macam keragaman, yaitu keragaman budaya, keragaman keyakinan (agama), keragaman suku, ras dan budaya. Dalam kehidupan bermasyarakat, interaksi sosial sangat diperlukan untuk mewujudkan kerukunan antar umat beragama dengan saling bergotong royong. Dengan cara inilah masing-masing umat beragama dapat saling menghormati, menerima perbedaan, serta hidup berdampingan dengan aman dan tentram. Dalam konteks toleransi antar umat beragama, Islam memiliki konsep yang sangat jelas yaitu "Tidak ada paksaan dalam agama, bagiku agamaku dan bagimu agamamu”. Hal ini merupakan contoh populer toleransi dalam agama Islam. Untuk mewujudkan toleransi tersebut dapat diwujudkan dengan membina tiga kerukunan hidup beragama, yaitu kerukunan intern umat beragama, kerukunan antar umat beragama, dan kerukunan antar umat beragama dengan pemerintah. Kegiatan pengabdian masyarakat dilakukan karena kurangnya pemahaman yang mengarah pada masyarakat umum, yang relatif rendahnya pengetahuan mengenai keagamaan di dalam masyarakat. Maka sikap moderasi beragama dengan menerapkan sikap toleransi perlu dibangun kepada masyarakat sebagai suatu pengakuan atas keberadaan pihak lain sebagai sikap menghormati adanya berbagai macam perbedaan. Perbedaan agama didalam masyarakat inilah yang menjadikan alasan untuk tidak saling menyakiti dan menghakimi justru saling mempersatukan. Metode ini menggunakan tahap wawancara yang dapat digunakan dalam bentuk wawancara secara langsung dengan beberapa narasumber. Dokumentasi yang dimaksud merupakan suatu usaha dari berbagai pengumpulan data yang di dapat dengan cara mengumpulkan hasil dari dokumen-dokumen yang bersangkutan dengan penelitian yang dilakukan oleh penulis. Dalam metode dokumentasi ini telah dilakukan untuk memperoleh data mengenai keadaan tempat lokasi yang diteliti baik dari segi geografis, keagamaan, tradisi, dan keadaan penduduk yang terdapat di Desa Gentasari. Hasil dari kegiatan yaitu, terlaksananya pengajin sesuai dengan tema Kuliah Kerja Nyata di Desa Gentasari, serta mengetahui toleransi dan interaksi yang ada di Desa Gentasari.

Kata Kunci: Moderasi Agama, Interaksi Sosial, Toleransi
\end{abstract}

\begin{abstract}
Moderation of religion in Indonesia is an important indicator and is used as a perspective (perspective) in all practices of religious life because Indonesia has various kinds of diversity, namely cultural diversity, diversity of beliefs (religion), ethnic diversity, race and
\end{abstract}


culture. In social life, social interaction is needed to create inter-religious harmony by working together. In this way, each religious community can respect each other, accept differences, and live side by side in a safe and peaceful way. In the context of inter-religious tolerance, Islam has a very clear concept, namely "There is no compulsion in religion, for me it is my religion and for you your religion". This is a popular example of tolerance in Islam. To realize this tolerance, it can be realized by fostering three religious harmony, namely internal harmony between religious communities, inter-religious harmony, and inter-religious harmony with the government. Community service activities are carried out due to a lack of understanding that leads to the general public, which is relatively low in knowledge about religion in society. So the attitude of religious moderation by applying an attitude of tolerance needs to be built to the community as an acknowledgment of the existence of other parties as an attitude of respect for various kinds of differences. Religious differences in society are what make the reasons not to hurt each other and judge each other to unite each other. This method uses the interview stage which can be used in the form of direct interviews with several sources. The documentation in question is an effort from various data collections that can be obtained by collecting the results of the documents concerned with the research conducted by the author. In this documentation method, it has been carried out to obtain data regarding the condition of the locations studied both in terms of geography, religion, tradition, and the condition of the population in Gentasari Village, and knowing the tolerance and interaction in Gentasari Village.

Key Word: Religious Moderation, Social Interaction, Tolerance

\section{Pendahuluan}

Agama menjadi pedoman bagi umat manusia untuk menuntut hubungan antara manusia dengan Tuhannya sesuai dengan kepercayaan agamanya masing-masing. Manusia juga diciptakan sebagai mahluk yang sempurna dan tentu memiliki kekurangan dan kelebihannya masing-masing. Sehingga manusia juga disebut dengan mahluk sosial yaitu mahluk yang tidak bisa hidup sendiri, serta perlu bantuan orang lain. Interaksi Sosial sangat diperlukan untuk mewujudkan kerukunan antar umat beragama. Maka pentingnya hidup saling melengkapi serta saling tolong menolong terhadap manusia satu dengan yang lainya merupakan aspek yang perlu diterapkan dalam kehidupan masyarakat, demi mewujudkan kehidupan yang aman serta damai (Suparman dkk, 2018). Adapun fakta dari keberagaman menunjukan bahwa Indonesia memiliki keaneragaman yang berbedabeda, maka jika dilihat dari sisi lain tentunya di dalam keberagaman terdapat ancaman bagi masyarakat. Maka disinilah perlu diterapkan kepada seluruh masyarakat khususnya masyarakat yang ada di Indonesia untuk saling mewujudkan kedamaian dan memperkuat rasa toleransi terhadap segala perbedaan (Huda dkk, 2020) (Linda, 2021).

Secara geografis Desa Gentasari merupakan salah satu dari 269 Desa di Kabupaten Cilacap yang memiliki luas wilayah $303 \mathrm{~km}^{2}$. Posisi Desa Gentasari terletak pada bagian timur Kecamatan Kroya dan berbatasan dengan Desa Paberasan Kecamatan Sampang. Sebagian besar penduduk Desa Gentasari bekerja pada sektor Pertanian, Perkebunan, Peternakan, dan sektor Perdagangan. Struktur penduduk menurut agama menunjukkan sebagian besar penduduk Desa Gentasari 
beragama, Islam, dan Kristen Protestan. Dari masyarakat di Desa Gentasari yang beragama Islam mayoritasnya memang agama islam merupakan agama yang turun menurun. Adanya agama Islam bukan merupakan dari masyarakat luar atau pendatang melainkan dari masyarakat asli dari Desa Gentasari. Sedangkan latar belakang dari agama Kristen Protestan atau agama minoritas, karena kebanyakan agama Kristen merupakan agama pindahan dari beberapa kepala keluarga yang pindah dan mentap di Desa Gentasari, Kecamatan Kroya, Kabupaten Cilacap. Untuk mengatur kemampuan pemahaman sebagai hasil belajar antara lain adalah membedakan, menyajikan, mengatur, menginterpretasikan, menjelaskan, mendemonstrasikan, memberi contoh dan mengambil kesimpulan (Purwanto, 2010).

Adanya kegiatan Kuliah Kerja Nyata, adanya kegiatan yang pertama kali dilakukan yaitu acara pengajian dengan tema Toleransi Q.S Al-Kafirun 1-6. Dari adanya kegiatan tersebut, masyarakat yang ada didesa Gentasari dapat mengetahui lebih jelas mengenai toleransi yang memang perlu diterapkan dilingkungan masyarakat atupun dimanapun saat masyarakat berada. Maka dalam kehidupan bermasyarakat perlu menjunjung tinggi perbedaan baik dari keyakinan dan cara beribadahnya, dengan kata lain, surat Al-Kafirun menegaskan bahwa toleransi sosial keagamaan didalam masyarakat perlu disikapi dengan rasa toleransi yang tinggi.

Dari kegiatan yang sudah dilaksanakan sebelumnya maka kegiatan berikutnya yaitu, mengunjungi masyarakat yang termasuk dalam masyarakat yang minoritas, dari kegiatan tersebut, penulis mewawancarai tokoh agama terkait interaksi dan toleransi yang ada di daerah tersebut sebagai masyarakat minoritas. Setelah wawancara yaitu, mengunungi Gereja Kristen Jawa yang terletak tidak jauh dari lokasi masyarakat minotitas tersebut. Sebagai peserta Kuliah Kerja Nyata ikut serta dalam membersihkan tempat ibadah umat kristen tersebut, sehingga peserta Kuliah Kera Nyata Tidak hanya membersihkan tempat Ibadah seperti Mushola dan Masjid saja, tetapi gereja sebagai tempat ibadah umat kristen tetap dibersihkan juga, dengan tidak membeda-mbedakan segala perbedaan, selagi segala aktivitas ataupun berbuatan baik dan tidak merugikan orang lain maka lebih baik dikerjakan.

\section{Metode}

Kegiatan dilaksanakan di Desa Gentasari Dusun Gunung Nangka, Kecamatan Kroya, Kabupaten Cilacap. Mekanisme dari kegiatan dilaksanakan dengan masyarakat sekitar dan tokoh agama minoritas yang ada di Desa Gentasari. Kegitan pertama yaitu mewawancarai tokoh agama yang berada di Desa Gentasari pada hari Kamis 05 Agustus 2021 di Desa Gentasari. Rumah dari tokoh agama tersebut tidak jauh dari gereja sehingga peneliti lebih mudah dalam melaksanakan kegiatan. Setelah melaksanakan wawancara yaitu mengunjungi gereja yang terletak di sebelah timur rumah tokoh agama tersebut. Gereja Kristen Jawa atau biasa disingkat dengan GKJ didirikan pada tahun 1978. Sebelumnya mayoritas dari warga yang 
bertempat tinggal di daerah Gereja Kristen Jawa beragama Kristen, namun lambat laun banyak dari masyarakat yang menjadi mualaf dan meninggal dunia sehingga Agama Kristen menjadi agama minoritas. Kegiatan bersama dengan tokoh dan pemuka agama Kristen dilaksanakan selama tiga kali pertemuan, yaitu dengan mengunjungi tokoh agama tersebut secara langsung kerumahnya dan tempat ibadah di daerah tersebut.

Kegitan keagamaan atau pengajian dilaksankan pada hari Jum'at, 13 Agustus 2021 yang bertempatan di Masjid Baitul Huda Al-Birr. Partisipasi warga sangat baik pada saat melaksanakan kegiatan pengajian dengan tema Toleransi Dalam Surat Al-Kafirun Ayat 1-6. Pengajian tersebut di hadiri oleh 35 Jama'ah dari masyarakat dengan pemateri Ustadz Sholeh. Ustadz Sholeh merupakan Tokoh Agama Islam yang terkenal dengan sosok yang baik dalam melaksanakan segala urusan agamanya dan memiliki sikap toleransi yang tinggi, sehingga dihadirkanlah sosok beliau untuk mengisi acara tersebut. Sebelum pengajian dimulai, terdapat kegiatan pembagian masker hal ini sebagai wujud untuk meningkatkan interaksi sosial yang baik dan keperdulian kepada jama'ah pengajian, selain itu sebagai salah satu hal yang terpenting untuk mematuhi protokol kesehatan di masa pandemi, faktor lain dari pembagian masker karena beberapa jama'ah pengajian tidak menggunakan masker, sehingga dari adanya kegiatan keagamaan tersebut, jama'ah yang hadir tetap melaksanakan kegiatan keagamaan sesuai dengan protokol kesehatan. Kegiatan dari pengajian merupakan kegiatan rutinan yang selalu dilaksanakan pada hari jum'at ba'da maghrib di Masjid Baitul Huda Al-Birr. Maka dari adanya kegiatan keagaam tersebut masyarakat yang ada di desa gentasari saling berinterkasi dan saling membaur antara satu dengan yang lainya, maka kerukunan akan semakin terlihat di Desa Gentasari.

Metode penilitian pada dasarnya merupakan cara ilmiah untuk mendapatkan data dengan tujuan dan kegunaan tertentu. Berdasarkan hal tersebut terdapat empat kata kunci yang perlu diperhatikan yaitu: Cara ilmiah, data, tujuan dan kegunaan. Cara ilmiah berarti kegiatan penelitian itu didasarkan pada ciri-ciri keilmuan yaitu rasional, empiris dan sistematis. Rasional berarti kegiatan penelitian itu dilakukan dengan cara-cara yang masuk akal sehingga terjangkau oleh penalaran manusia. Empiris berarti cara-cara yang dilakukan itu dapat diamati oleh indra manusia, sehingga orang lain dapat mengamati dan mengetahui cara-cara yang digunakan. Sistematis artinya proses yang digunakan dalam penelitian itu menggunakan langkah-langkah tertentu yang bersifat logis. (Sugiyono, 2012). Observasi ini penulis gunakan untuk melihat praktik interaksi sosial Antarmasyarakat Melalui Moderasi Beragama Dan Sikap Toleransi di Desa Gentasari dengan mengikuti dan melihat kegiatan keagamaan yang dilakukan oleh masyarakat Desa Gentasari. Yang Kedua yaitu Wawancara dalam penelitian kualitatif tidak bersifat netral, melainkan dipengaruhi oleh kreativitas individu dalam merespon realitas dan situasi ketika berlangsungnya wawancara (Hartono, 2021). 
Kegunaan wawancara untuk melengkapi data yang sebelumnya telah diperoleh melalui proses observasi, dalam penulisan artikel jurnal ini dilakukan untuk mendapatkan data dengan menggali informasi dan data terkait interaksi sosial yang ada di Desa Gentasari, dengan sikap toleransi yang terjalin di dalam masyarakat dengan mencari makna maupun faktor dan bentuk interaksi sosial, serta bagaimana kehidupan toleransi yang ditunjukan oleh masyarakat Desa Gentasari, Kecamatan Kroya, Kabupaten Cilacap melalui beberapa informan di antaranya oleh tokoh masyarakat agama Desa Gentasari. Selain itu, warga yang pernah mengikuti kegiatan sosial maupun kegiatan keagamaan di Desa Gentasari Kecamatan Kroya, Kabupaten Cilacap. Dan tahap ini, wawancara yang digunakan dalam bentuk wawancara secara langsung dengan beberapa narasumber. Dokumentasi yang dimaksud merupakan suatu usaha dari berbagai pengumpulan data yang di dapat dengan cara mengumpulkan hasil dari dokumen-dokumen yang bersangkutan dengan penelitian yang dilakukan oleh penulis. Dalam metode dokumentasi ini telah dilakukan untuk memperoleh data mengenai keadaan tempat lokasi yang diteliti baik dari segi geografis, keagamaan, tradisi, dan keadaan penduduk yang terdapat di Desa Gentasari. Dokumentasi dapat dilakukan pada saat observasi di lapangan maupun ketika mengikuti kegiatan sosial dan keagamaan pada saat melaksankan kegitan di Desa Gentasari, Kecamatan Kroya, Kabupaten Cilacap.

\section{Hasil dan Pembahasan}

Pelaksanaan kegiatan dilakukan Di Dusun Gunung Nangka, Desa Gentasari, Kecamatan Kroya Kabupaten Cilacap. Dengan Pemateri Ustadz Sholeh, dan di Hadiri 35 Jama'ah dari beberapa masyarakat. Tema pengajian yaitu Toleransi Menrut Perspektif Q.S Al-Kafirun. Ayat yang terdiri dari 6 ayat, merupakan pengakuan eksistensi secara timbal balik, bagi kamu agama kamu dan bagiku agamaku. Sehingga dengan demikian masing-masing pihak dapat melaksanakan apa yang dianggapnya benar dan baik, tanpa memutlakkan pendapat kepada orang lain tetapi sekaligus tanpa mengabaikan keyakinan masing-masing ( Az-Zuhaili: 2012)

Batasan adanya pemisah antara pemeluk agama telah memberi ruang kepada setiap manusia agar bertanggung jawab atas apa segala sesuatu yang disudah dipilih sesuai dengan kehendak dan kemauan dalam hati, yang telah diyakini dan dikerjakan karena tidak ada paksaan dalam agama. Karena agama memiliki konsep bahwa penerimaan dengan suka hati, kebebasan untuk memilih. Dan disinilah landasan serta tanggung jawab setiap manusia atas apapun yang telah dikerjakan. Maka setiap manusia akan mengerti akibat dari segala perbuatan, dan keyakinan yang telah diucapkan. Segala urusan didalam masyarakat, baik itu tradisi yang sudah menjadi warisan secara turun temurun tidak lagi menjadikan suatu masalah, maka setiap manusia dituntut untuk menentukan pilihan nya ataupun keyakinannya sesuai dengan keyakinan yang telah di kehendaki. 

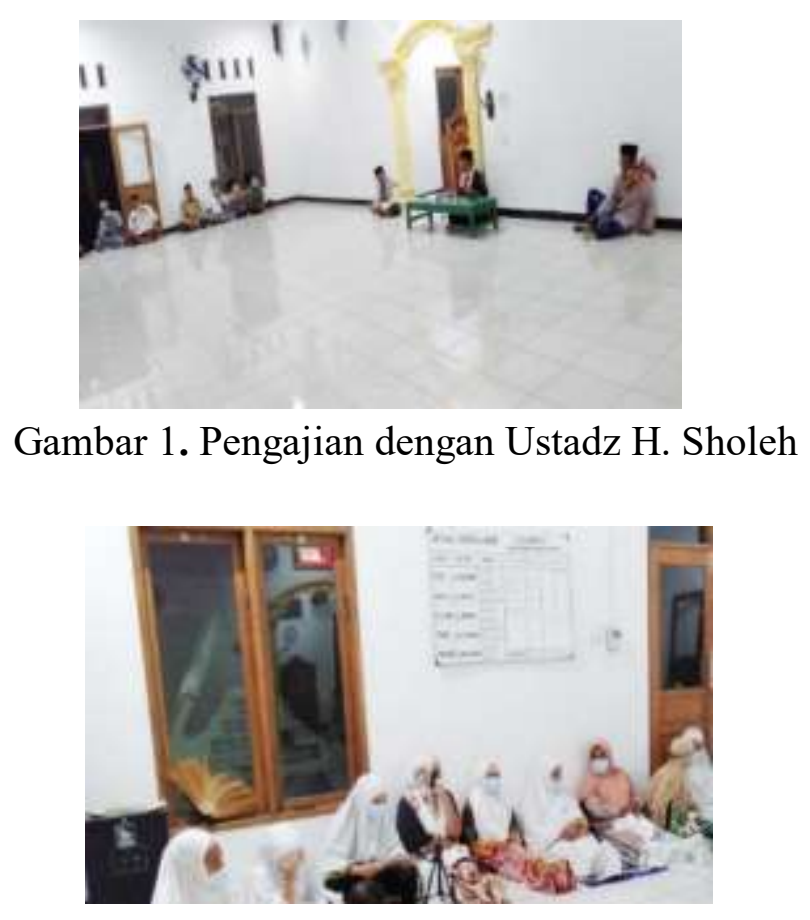

Gambar 2. Jama'ah Pengajian

Tujuan dengan adanya kegiatan dari pengajian tersebut maka masyarakat secara langsung berinteraksi dengan masyarakat lainya. Sehingga dengan adanya kegiatan pengajian masyarakat akan lebih sadar pentingnya interaksi untuk mewujudkan suatu kebersamaan demi menciptakan kedamaian antar sesama umat beragama, dan dari masyarakat yang beragama muslim akan lebih memahami bagaimana bersikap dengan masyarat yang memiliki keyakinan yang berbeda dengan diselenggarakannya pengjian dengan tema tersebut.

Gereja Kristen Jawa (GKJ) terletak di Desa Gunung Nangka Gereja ini sudah ada sejak tahun 1978 hingga saat ini. Kegiatan ibadah yaitu mingguan. Sebelum adanya covid, terdapat pemahaman Al-Kitab. Dan dari kegiatan tersebut Ibu jadi mengatakan bahwa "Di Desa gentasari toleransinya sangat baik. Mereka tidak beranggapan apapun dan tidak membeda membedakan. Tetapi jika ada yang yang mengatakan apa-apa saya tidak tahu. Pada saat kegiatan tradisi sedekah bumi misalnya, semua warga berkumpul di halaman rumah saya, karena agama saya agama minoritas, dari tokoh agama muslim yang memimpin doa, saya tidak pergi, karena saya menghormati” (Ibu Jadi, 2021).

Sedangkan pelaksanaan kegiatannya wawancara dengan agama minoritas yaitu dilaksanakan dirumah tokoh agama, awalnya kegiatan dari wawancara tersebut mengenai sejarah pembangunan gereja katolik, dan pendapat mengenai toleransi yang ada di Dusun Gunung Nangka, Desa Gentasari, Kecamatan Kroya, Kabupaten Cilacap. 


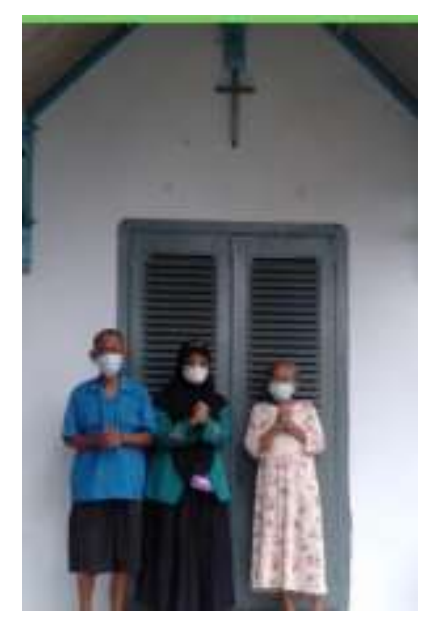

Gambar 3. Kunjungan Gereja Kristen Jawa

Penerapan interaksi sosial antar masyarakat ini adalah dimana tindakan dari individu saaat menanggapi pendapat dari orang lain. Hal tersebut dilandasi dari fokus sosiologi yaitu gagasan bahwa manusia berperilaku berbeda ketika berada dalam suatau kelompok didalam masyarakat. Menurut teori dari interaksi sosial masyarakat, telah ditentukan oleh tekanan sosial yang dihadapi. Artinya perilaku dapat diciptakan oleh salah sebagain orang terhadap respon yang ada dilingkungannya. Di Desa Gentasari interaksinya antar masyarakatnya memiliki serangkaian perilaku dan sikap unik tersendiri.

Menurut pandangan dari ibu laminah sebagai masyarakat yang beragama minoritas di Desa Gentasari bahwa "Diluar sana memang banyak orang yang saling bertikai secara terbuka maupun tertutup karena masalah kepercayaan ataupun yang terkait dengan agama, tetapi Di Desa Gentasari, saya merasakan baiknya itu toleransi, di daerah sini, mayoritas memang beragama islam tetapi tetanggatetangga kita itu baik sekali semuanya tidak ada yang fanatik atau mengungkitungkit masalah agama atapun yang lainya, jadi betul-bagus toleransi di daerah saya ini" (Laminah, 2021).

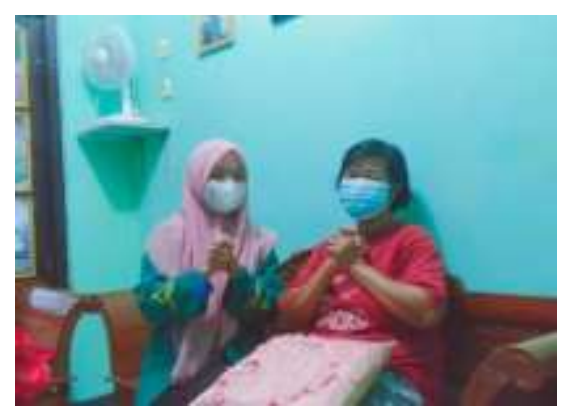

Gambar 3. Wawancara dengan Tokoh agama Kristen Protestan

Jika terdapat konflik agama dan apabila kita sebagai seorang muslim tidak bertindak maka cepat atau lambat perpecahan umat akan terjadi, maka pentinya 
melandasi keimanan dan ketaqwaan sebagai umat Islam terhadap umat yang berbedaa agama, karena islam juga merupakan agama perdamaian. Di era sekarang dapat dilihat dengan sendirinya bahwa telah terjadi perpecahan di dalam masyarakat.

Dalam penelitian yang selama ini di jalankan di Desa Gentasari moderasi agama warga tersebut cukup baik. Cara manusia berinteraksi dalam masyarakat juga dapat menentukan perilaku manusia tersebut. Melalui interaksi timbal balik, individu saling berhubungan saling maka terbentuklah suatu masyarakat yang saling tolong menolong serta saling bekerjasama antara satu dengan yang lainya

Tabel 1. Uraian Kegiatan

\begin{tabular}{|c|c|c|}
\hline No. & Uraian Kegiatan & Keterangan \\
\hline 1 & $\begin{array}{c}\text { Pengajian Tema "Toleransi Q.S Al- } \\
\text { Kafirun 1-6" }\end{array}$ & $\begin{array}{l}\text { Berhasil } \\
\text { Dari adanya kegiatan } \\
\text { pengajian dengan tema } \\
\text { Toleransi Q.S Al- Kafirun 1-6 } \\
\text { terdapat } 35 \text { Jama'ah dengan } \\
\text { pemateri dan materi yang } \\
\text { mudah dipahami oleh } \\
\text { kalangan masyarakat }\end{array}$ \\
\hline 2 & Mengunjungi Gereja Kristen Jawa & $\begin{array}{l}\text { Berhasil } \\
\text { Kunjungan dengan peserta } \\
\text { Kulih Kerja Nyata telah } \\
\text { dilaksankan dengan } \\
\text { mengetahui sejarah apa saja, } \\
\text { dari adanya gereja yang ada } \\
\text { di desa tersebut, serta sejarah } \\
\text { pembangunan gereja } \\
\text { dilingkungan masyarakat } \\
\text { yang beragama Islam }\end{array}$ \\
\hline 3 & $\begin{array}{c}\text { Wawancara Dengan Tokoh Agama } \\
\text { Minoritas }\end{array}$ & $\begin{array}{l}\text { Berhasil } \\
\text { Wawancara dengan tokoh } \\
\text { masyarakat yang bergama } \\
\text { Kristen mengenai interaksi } \\
\text { dan toleransi yang ada di desa } \\
\text { gentaari }\end{array}$ \\
\hline
\end{tabular}

\section{Kesimpulan}

Kajian ini membahas mengenai bagaimana Penerapan Interaksi Sosial Antar Masyarakat Melalui Moderasi Beragama dan sikap toleransi. Di Desa Gentasari, Kecamatan Kroya, Kabupaten Cilacap. Moderasi beragama yang berada di gentasari memang cukup baik tetapi dengan adanya kegiatan gotong royong, 
kegiatan keagamaan, kegiatan kebudayaan, dan kegiatan tradisi tentu akan menumbuhkan interaksi sosial dalam masyarakat yang jauh lebih baik.

Adapun dari beberapa kelompok budaya yang ada di gentasari, moderasi keagamaan dalam keragaman dan peran penyuluhan agama dalam mewujudkan kedaiaman yang ada di Desa Gentasari ini tetap perlu dikembangkan untuk persatuan dan kedamaian didalam masyarakat, maka sikap inilah perlu ditingkatkan dengan pengakuan atas keberadaan pihak lain, memiliki sikap toleran, penghormatan atas perbedaan pendapat dan tidak memaksakan kehendak dengan cara kekerasaan, maka peran pemerintah, tokoh masyarakat, dan para penyuluh agama sangat penting untuk mensosialisasikan serta menumbuhkembangkan moderasi beragama kepada masyarakat agar tetap terwujudnya keharmonisan dan kedaiaman. Fakta dan data keragaman agama-agama di desa Gentasari menunjukkan bahwa kehidupan keagamaan di Desa Gentasari cukup baik.

\section{Ucapan Terimakasih}

Alhamdulillah, karena penulis telah menyelesaikan jurnal. Jurnal ini diperuntukan untuk mahasiswa, dan masyarakat ataupun peminat dari referensi atau gambaran terkait dengan Penerapan Interaksi Sosial Antar Masyarakat Melalui Moderasi Beragama Dan Sikap Toleransi di Desa Gentasari Kecamatan Kroya Kabupaten Cilacap. Dalam kesempatan ini saya ingin menyampaikan ungkapan terimakasih kepada: 1.Dosen Pembimbing Lapangan, Bapak Asep Amaludin, S.Pd,. M.Si yang telah membimbing saya dan teman-teman dengan sangat baik. 2. Orang tua, Ibu Endang dan Alm.Bapak Darwan serta keluarga yang selalu menjadi support terbaik. 3. Pihak yang sudah ikut berkontribusi dalam pembuatan jurnal pengabdian masyarakat. Terutama dari pihak Masyarakat Desa Gentasari, Ibu laminah dan ibu jadi (Tokoh Agama Minoritas) dan Ustadz Sholeh selaku pembawa materi pada saat pengajian di Desa Gentasari yang sudah ikut dalam menyukseskan pembuatan jurnal ini. Penulis menyadari masih banyak kekurangan, maka penulis memohon maaf.

\section{Daftar Pustaka}

Al-Munawar, S.A. (2003). Fiqih Hubungan Antar Agama. Jakarta: Ciputat Press.

A.Jamrah, S. (2017). Toleransi Antar Umat Agama Dalam Perspektif Islam. Jurnal. (2017),

Anita, K.N. (2016). Kajian Krisis Tentang Toleransi Beragama dalam Islam, $A L-$ Hikmah: Jurnal Studi Agama-Agama, Vol. 2 No. 2, (2016).

Darlis. (2017). Mengusung Moderasi Islam di Tengah Masyarakat Multikultural. Rausyan Fikr, Vol.13 No. 2 Desember, 225-255.

Fahrudin. (2019). Pentingnya Moderasi Beragama bagi Penyuluh Agama. Republika. 
Faridah, I.F. (2013).“ Toleransi antar umat beragama masyarakat perumahan”. Komunitas, Vol. 5, No 1, Hal 14-25.

Hanafi, M. (ed). (2017). Moederasi Islam. Jakarta: Lajnah Pentasihan Mushaf Alquran, Badan Litbang dan Diklat Kementrian Agama RI.

Hendropuspito. (1983). Sosiologi Agama. Yogyakarta: KANISIUS.

Herdiansyah, Haris. (2011). Metodologi Penelitian Kualitatif untuk Ilmu-ilmu Sosial. Jakarta: Salemba humanika.

Huda, N., Mardiana, N., \& Imayah, I. (2020). Strategi Pembelajaran bagi Guru di Lembaga Pendidikan Islam Anak Sholeh Pepelegi, Sidoarjo. To Maega: Jurnal Pengabdian Masyarakat, 3(2), 111-121.

Khotimah. (2016). Interaksi Sosial Masyarakat Islam dan Kristen Di Dusin IV Tarab Mulian Kecamatan Tambang Kabupaten Kampar, Jurnal Penelitian Keagamaan. Vol. 19, No. 2 Juli-Desember.

Kementrian Agama RI. (2015). Naskah Akademik Bagi Penyuluh Agama Puslitbang Kehidupan Keagamaan. Jakarta.

Mannuhung, S., Tenrigau, A. M., \& Didiharyono, D. (2018). Manajemen Pengelolaan Masjid dan Remaja Masjid di Kota Palopo. To Maega: Jurnal Pengabdian Masyarakat, 1(1), 14-21.

Mas'ud, A. (2018). Strategi Moderasi Antarumat Beragama. Jakarta: Kompas.

Nugraha. (2008). Wawasan Multikultural. Bandung: BDK Bandung.

Rakhmat, C. (2008). Paradigma Konseling Berbasis Budaya: Metateori yang membumikan Konseling dalam konteks Budaya. Pidato pengukuhan Guru Besar pada FIP UPI. Bandung : UPI.

Pengembangan Kompetensi Penyuluh Agama pada Ditjen Bimas Islam Kementerian Agama RI dalam Memelihara Kerukunan Umat Beragama. Tangerang: Young Progressive Muslim. 